\title{
A Study on the Armillary Spheres of the Confucianists in Joseon Dynasty
}

\author{
Yong Sam Lee ${ }^{1,3 \dagger}$, Sang Hyuk Kim ${ }^{2,3}$, Min Soo Lee ${ }^{1}$, and Jang Hae Jeong ${ }^{1,3}$ \\ ${ }^{1}$ Department of Astronomy and Space Science, Chungbuk National University, Cheongju 361-763, Korea \\ ${ }^{2}$ Basic Science Research Institute, Chungbuk National University, Cheongju 361-763, Korea \\ ${ }^{3}$ Chungbuk National University Observatory, Cheongju 361-763, Korea
}

Armillary sphere, generally known as, not only astronomical instrument for observing astronomical phenomena but also symbolizes the royal authority and royal political ideology which is based on Confucianism. Among the well-reputed Confucian scholars were built their own armillary spheres. However, these armillary spheres which exist are damaged and most of parts of its have been lost. We analyzed and measured the remnants of armillary spheres which were made by Toegye Lee Hwang, Uam Song Si-Yeol and Goedam Bae Sang-Yeol who were well-reputed Confucian scholars in Joseon Dynasty, and have been executed the restorations of Toegye Lee Hwang and Song Si-Yeols armillary sphere based on the drawings which were drawn as the original form by analysis and measurement of its remnants.

Keywords: armillary sphere, restoration, Confucian scholar (Toegye, Uam, Goedam)

\section{INTRODUCTION}

The armillary sphere was a traditional astronomical instrument in East Asia designed to measure the location of celestial bodies. As such, it has the function to measure time and seasons. The armillary sphere, whose shape was crafted on the "egg-like hypothesis (Honcheonseol)", surrounds the celestial sphere in a circle from the observer's perspectives. The structure of an armillary sphere allows the user to observe the location of celestial bodies on the celestial sphere by the equatorial coordinates system centered on the North Pole, and also to estimate the location of the horizontal coordinates system and the ecliptic coordinates system through the horizontal ring and the ecliptic ring. The rotation axis of the armillary sphere has the same structure as that of the equatorial coordinates system in modern astronomy, and it is in the same direction of the sky's North Pole. It can excellently measure the Ipsudo (similar to right ascension value) of the equatorial coordinates system and Geogeukdo (similar to declination value), as well as makes it convenient to observe and understand the movement of celestial bodies on the celestial sphere. The basic structure of the armillary sphere consists of three-layer rings. The outer layer consists of Yukhapui (fixed outer terrestrial-coordinate component); the middle layer, Samsinui (revolving sidereal component); the inner layer, Sayuui.

The armillary sphere was not only an instrument designed to observe the astronomical phenomena, but also an instrument designed to symbolize the monarchical authority and embody the monarchical politics on the basis of Confucian ideologies (Lee et al. 2001). Joseon's kings, who embraced the duty of observing astronomical phenomena and identifying the time and providing the information to the people, manufactured diverse armillary spheres and Honcheonsigye (armillary clock), which have not nearly survived to present day. Joseon's well-reputed Confucian scholars manufactured armil- (c) This is an Open Access article distributed under the terms of the Creative Commons Attribution Non-Commercial License (http://creativecommons.org/licenses/by-nc/3.0/) which permits unrestricted non-commercial use, distribution, and reproduction in any medium, provided the original work is properly cited.
Received Jun 18, 2010 Revised Oct 14, 2010 Accepted Oct 20, 2010 ${ }^{\dagger}$ Corresponding Author

E-mail: leeysam@hanmail.net

Tel: +82-43-261-2314 Fax:+82-43-261-2312 
lary spheres.

Among armillary spheres which were used by Toegye Lee Hwang (1501 1570), Uam Song Si-Yeol (1607 1689), Goedam Bae Sang-Yeol (1759 1789) and etc, some of their components or some damaged instruments are extant. One of the Four Books (Saseo) and Three Classics (Samgyeong), the Class of History, which was a must-read book for Confucian scholars, says that King Shun (Chinese leader) crafted Seongiokhyeong (armillary sphere), an astronomical instrument, to observe the sun, the moon, and the five planets. Scholars trained in the way of nature by performing astronomical observation with armillary spheres, and Confucian scholars, who aimed to achieve the unification of the heaven and man, studied the rise and fall of the sun, the moon and five planets so as to pursue the study of things and nature, the basis of studies.

Confucian scholars attached importance to astronomical observation because they believed that all ways, the most fundamental principle of Confucianism, come from the heaven. In particular, it was important Confucian thought that kings and bureaucrats should know the will of the heaven and accordingly rule the people. Also, the armillary sphere was considered an important instrument to allow Confucian scholars to know and understand what would happen in the heaven as well as the principle of how that would happen on the basis of one of basic Confucian principles, respecting the people's will and following the will of the heaven.

However, some extant armillary spheres dating back to the Joseon period have suffered damage; their components are damaged and their rings are misplaced and damaged. In this study, the components of extant armillary spheres used by Toegye, Uam, and Goedam were measured and analyzed, and their design drawings were crafted in order to restore these relics, and thus Toegye's and Uam's armillary spheres were restored.

\section{INVESTIGATION OF ARMILLARY SPHERES}

Scientific investigations were leaded to restore the operating models of armillary spheres used by Confucian scholars. Extant relics were measured, damaged parts were analyzed, and the size and structures of extant armillary spheres were investigated. Table 1 shows the results of scientific investigations into the extant armillary spheres used by Toegye, Goedam, and Uam.

\subsection{Toegye Armillary Sphere}

The armillary sphere of Toegye (hereinafter Toegye armillary sphere) is on display at Okjingak (Okjingak pavilion) of Dosanseowon (Dosan Confucian Academy) near Andong-si, Gyeongsangbuk-do. Some components of armillary sphere, namely, components of various rings along with Honsang (celestial globe) are exhibited there. Their shapes and structures are hard to figure out, but Goedam Bae Sang-Yeol observed the armillary sphere on display there and crafted one in 1779 (Jeong et al. 2007).

\subsection{Goedam Armillary Sphere}

The armillary sphere of Goedam (hereinafter Goedam armillary sphere), as mentioned earlier, after visiting Dosanseowon, Goedam observed the Toegye armillary sphere and crafted one. Our measurement and investigations of the Goedam armillary sphere revealed that all of its components were made of wood (Table 1). The pole of polar axis which is basic drive shaft, the Gyuhyeong (sighting alidade) which is a surveying device and the Ounju (turtle pillar) that supports the center of the armillary sphere were lost and only some components have been left as damaged. Various rings, some of which were lost, are tied in a bundle.

This armillary sphere has the same structure as that of an ordinary armillary sphere, except that its Jeokdodanhwan (revolving equator single ring) is wide, and that traditional Korean paper, attached inside the Jeokdodanhwan, features the pictures and names of 28 constellations. This distinguishes it from other armillary spheres, allowing it to easily explain the method of observing celestial bodies. Fig. 1 shows the extant Goedam armillary sphere. Actual measurements and characteristics of each component are outlined in Table 2. In particular, 23 characters are engraved at the bottom of the Sipjabachim (cross support). These letters are written "it was first crafted in the year of Gihae (1779, at the age of 21 years), and it was renovated in the year of Eulsa (1785, at the age of 27 years) but was not elaborately crafted because of the poor material and inadequate skills; thus, it should be renovated again using better techniques and better wood."

\subsection{Uam Armillary Sphere}

The armillary sphere of Uam (hereinafter Uam armillary sphere) was used by Song Si-Yeol for teach his students while he was residing in Hwayang-dong after leaving the political circles. It is now kept by Cheongju National Museum after it was well preserved by his descendants. Ac- 
cording to his descendant, Mr. Song Yeong-Dal ${ }^{1}$, it could be preserved because it was buried under the ground during the Korean War. The frame of this armillary sphere which is made of wood and tied with strings is remain but various metal rings are either lost or corroded or partly damaged or misplaced (See Table 1 and Fig. 2). 24 directions were engraved on outer side of wooden horizontal

${ }^{1}$ When the writer visited him to his residence at Cheongju-si, he showed the Uam armillary sphere to the writer, and mentioned so in 1997. ring and also each direction divided into two specific directions for closer direction measurement so wooden horizontal ring shows 48 directions.

Its various metal rings each feature carvings of accurate scale marks. Its wooden Yongju (dragon pillar) emblems and sculptures are the most artistic of the extant armillary spheres. Lee (2007) revealed that the Uam armillary sphere was used not for actual observation but for educational purpose. His literary quotation says, "The teacher (Uam) says that it is difficult to understand

Table 1. Armillary spheres of Toegye, Goedam and Uam.

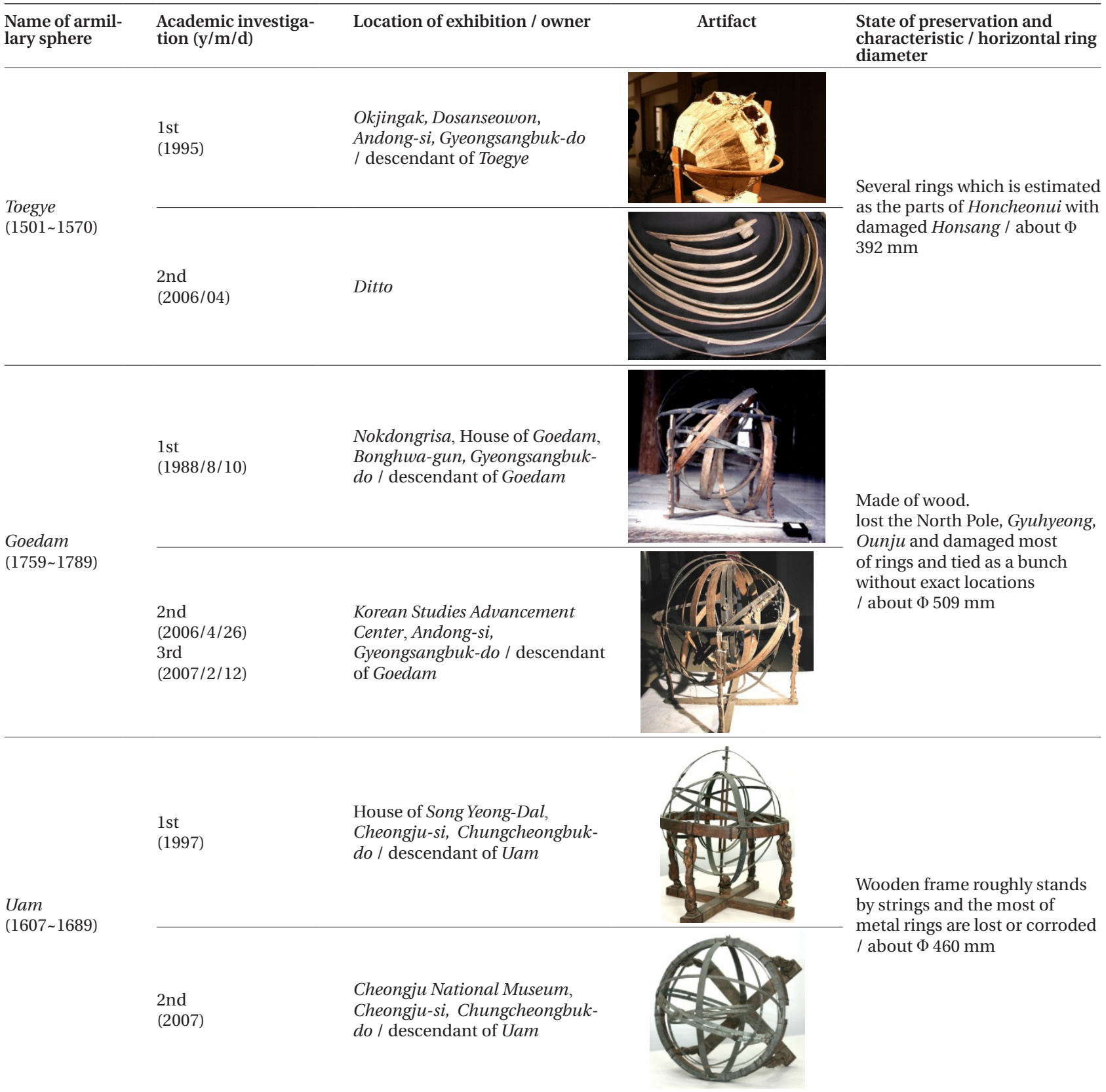




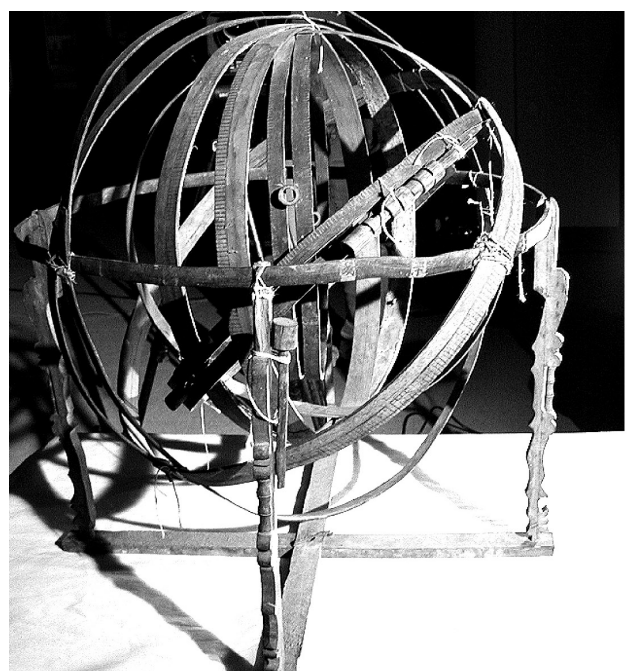

(a)

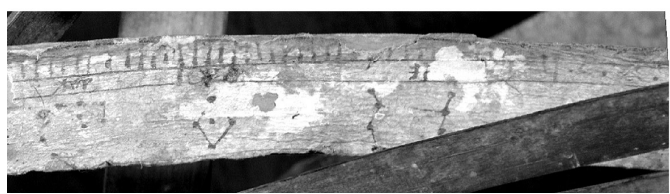

(d)

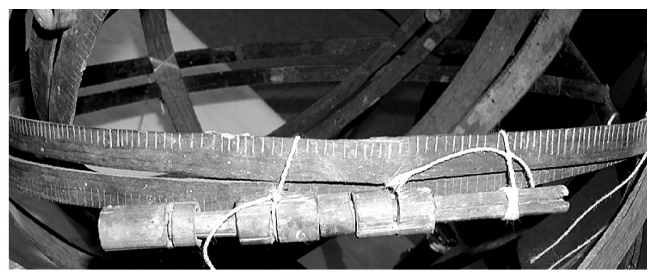

(b)

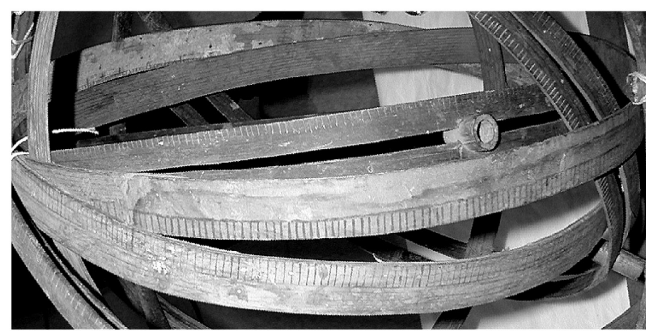

(c)

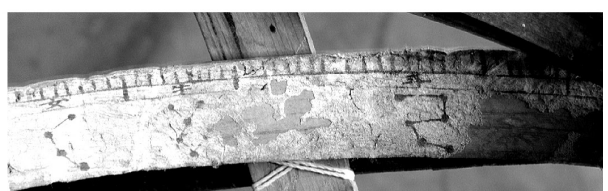

(e)

Fig. 1. Goedam armillary sphere. (a) front view. (b) Samsinheukssanghwan and broken pole-axis. (c) Samsinheukssanghwan, Jeokdodanhwan, Hwangdodanwhan. (d) and (e) Jeokdodanhwan's 28 Su names and constellations: Yu, Gwi, Jeong, Sam, Yeo, U, Du, Gi.
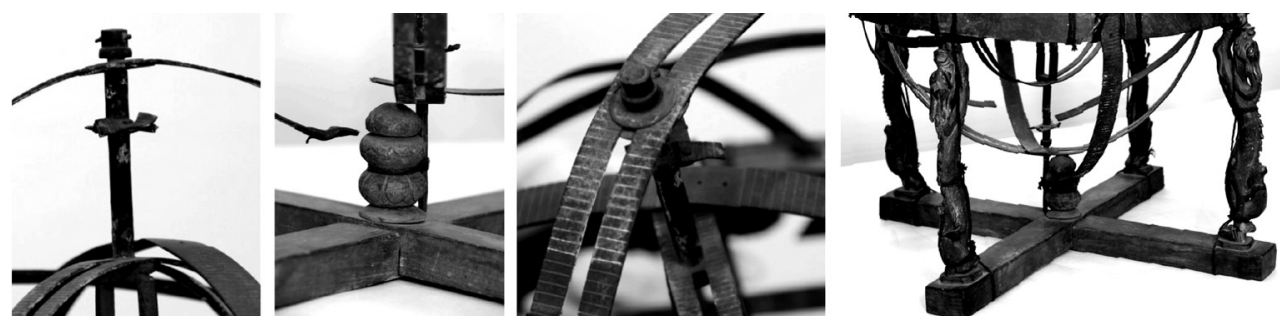

Fig. 2. Damaged parts of Uam armillary sphere.

with pictures alone. It is not difficult to know if one attempts to examine the reason for crafting the device". He also revealed that the Uam armillary sphere was crafted by Lee Min-Cheol (1631 1715). Lee Min-Cheol crafted a water-operated armillary sphere in 1669 (10th year of the reign of King Hyeonjong), and was the then best expert on armillary spheres. He was well versed in astronomical instruments, calendar and sciences. Uam, while serving as a governor in 1680 (the 6th year of the reign of King Sukjong), gave a detailed explanation on the principle of solar eclipse to the king in a feast. ${ }^{2} \mathrm{Uam}$ also gave the explanation on the principle of Honcheonsigye (armillary clock) crafted by Lee Min-Cheol during the reign of King Sukjong.

${ }^{2}$ Changgyejip, a Collection of Literary Works, vol. 18: 17ab; Gyeongyeonnok

\section{DESIGN AND RESTORATION OF ARMILLARY SPHERES}

Design drawings were crafted on the basis of the actual measurement of the various components of Toegye, Goedam and Uam armillary sphere. Table 2 shows a comparison of the specifications and characteristics between the Toegye ${ }^{3}$, Goedam and Uam armillary sphere and the astronomical clock and armillary sphere crafted by Song I-Yeong (1619 1674) (Kim 2007). Song I-Yeong's armillary sphere is linked to the alarm clock of the astronomical clock, now National Treasure No. 230, which was manufactured at the 10th year of reign of King Hyeonjong (1669),

${ }^{3}$ Extant Toegye armillary sphere components were measured, and the Goedam armillary sphere crafted on the basis of the Toegye armilary sphere was examined, so as to determine the whole measurement of the armillary sphere. 
Table 2. Comparison of Toegye, Goedam, Uam and Song I-Yeong armaillary sphere.

\begin{tabular}{|c|c|c|c|c|c|c|c|c|}
\hline \multirow{2}{*}{ Part } & \multirow{2}{*}{ Ring } & \multirow{2}{*}{$\begin{array}{l}\text { Toegye } \\
\mathrm{Ed}(\mathrm{W}) \mathrm{T} \\
/ \mathrm{mm}\end{array}$} & \multicolumn{2}{|l|}{ Goedam } & \multicolumn{2}{|l|}{ Uam } & \multicolumn{2}{|c|}{$\begin{array}{l}\text { Song I-yeong } \\
\text { (national treasure no. 230) }\end{array}$} \\
\hline & & & $\begin{array}{l}\mathrm{Ed}(\mathrm{W}) \mathrm{T} \\
/ \mathrm{mm}\end{array}$ & $\begin{array}{l}\text { Characteristic and } \\
\text { structure }\end{array}$ & $\begin{array}{l}\operatorname{Ed}(\mathrm{W}) \mathrm{T} \\
/ \mathrm{mm}\end{array}$ & $\begin{array}{l}\text { Characteristic and } \\
\text { structure }\end{array}$ & $\begin{array}{l}\operatorname{Ed}(W) \mathrm{T} \\
/ \mathrm{mm}\end{array}$ & $\begin{array}{l}\text { Characteristic and } \\
\text { structure }\end{array}$ \\
\hline \multirow[t]{3}{*}{ Yukhapui } & $\begin{array}{l}\text { Cheongyeong- } \\
\text { heukssangh- } \\
\text { wan }\end{array}$ & $\begin{array}{l}398 \\
(13) \\
3\end{array}$ & $\begin{array}{l}\text { State of } \\
\text { cut } \\
(15.1)\end{array}$ & $\begin{array}{l}\text { made of pine, } 10 \text { black } \\
\text { scale marks engraved } \\
\text { L: } 40 \mathrm{~mm}, 8.6 \mathrm{~mm}\end{array}$ & $\begin{array}{l}440 \\
(32)\end{array}$ & $\begin{array}{l}\text { scale marks en- } \\
\text { graved on outer } \\
\text { of each ring every } \\
3.7 \mathrm{~mm} \text { interval }\end{array}$ & $\begin{array}{l}390 \\
(13.8) \\
2.9\end{array}$ & $\begin{array}{l}\text { Double ring, black } \\
\text { altitude: about } 37.5 \\
\text { degrees } \\
\text { outer interval: } 21 \mathrm{~mm}\end{array}$ \\
\hline & $\begin{array}{l}\text { Cheonwijeok- } \\
\text { danhwan }\end{array}$ & $\begin{array}{l}398 \\
(13) \\
3\end{array}$ & $\begin{array}{l}397 \\
(30.5)\end{array}$ & $\begin{array}{l}\text { Width of jucheondo: } 12 \\
\text { center line: } 2 \mathrm{~mm}\end{array}$ & $\begin{array}{l}440 \\
(22.5)\end{array}$ & $\begin{array}{l}\text { same as Cheon- } \\
\text { gyeongheukssang- } \\
\text { hwan }\end{array}$ & $\begin{array}{l}400 \\
(13.8) \\
2.9\end{array}$ & $\begin{array}{l}\text { Single ring, red } \\
360 \text { degrees scale marks } \\
\text { on inner side of North } \\
\text { and South side each }\end{array}$ \\
\hline & Jipyeonghwan & $\begin{array}{l}392 \\
(13) \\
10\end{array}$ & $\begin{array}{l}509 \\
(17.4)\end{array}$ & $\begin{array}{l}24 \text { directions marked } \\
\text { on edge of black } \\
\text { Jipyeonghwan which } \\
\text { made of bamboo }\end{array}$ & $\begin{array}{l}460 \\
(22) \\
\text { metal:2 } \\
\text { wood:35 }\end{array}$ & $\begin{array}{l}24 \text { directions } \\
\text { marked on edge of } \\
\text { Jipyeonghwan } \\
\text { and each direction } \\
\text { also divided as two } \\
\text { part so it makes } 48 \\
\text { directions }\end{array}$ & $\begin{array}{l}413 \\
(20) \\
\text { metal:3.2 } \\
\text { wood:25.5 }\end{array}$ & $\begin{array}{l}\text { Single ring, black } \\
\text { carved } 24 \text { directions on } \\
\text { upper side } \\
24 \text { solar terms to Myo, } \\
Y u \text { direction }\end{array}$ \\
\hline \multirow[t]{4}{*}{ Samsinui } & $\begin{array}{l}\text { Samsinheuks- } \\
\text { sanghwan }\end{array}$ & $\begin{array}{l}318 \\
(13) \\
3\end{array}$ & $\begin{array}{l}441 \\
(14.7)\end{array}$ & $\begin{array}{l}\text { Made of bamboo, } \\
\text { black, width of scale } \\
\text { mark: } 7.0 \rightarrow 10.5 \mathrm{~mm} \\
\text { diameter of metal: } 21.1 \\
\text { mm I.d. of pole: } 9.2 \\
\text { mm interval of double } \\
\text { ring: } 3 \mathrm{~mm}\end{array}$ & $\begin{array}{l}\text { estimated } \\
380 \text { degrees }\end{array}$ & lost & $\begin{array}{l}350 \\
(15) \\
3.5\end{array}$ & $\begin{array}{l}\text { Double rings, black } \\
\text { outer interval: } 21\end{array}$ \\
\hline & $\begin{array}{l}\text { Jeokdodan- } \\
\text { hwan }\end{array}$ & $\begin{array}{l}318 \\
(13) \\
3\end{array}$ & (30.5) & $\begin{array}{l}\text { Made of pine, blurred } \\
\text { red, width of scale } \\
\text { mark: } 17.6 \mathrm{~mm} \text { names } \\
\text { of } 28 \text { constellations }\end{array}$ & $\begin{array}{l}380 \\
(11.3) \\
1.5\end{array}$ & $\begin{array}{l}\text { engraved jucheon- } \\
\text { do on outer side of } \\
\text { metal goods } \\
\text { ( } 365.25 \text { degrees) }\end{array}$ & $\begin{array}{l}350 \\
(12.6) \\
2.8\end{array}$ & $\begin{array}{l}\text { Single ring, red } \\
\text { carved Jucheondo } \\
\text { ( } 365.25 \text { degrees) on the } \\
\text { outer side of the North } \\
\text { and South each side }\end{array}$ \\
\hline & $\begin{array}{l}\text { Hwangdodan- } \\
\text { hwan }\end{array}$ & $\begin{array}{l}318 \\
(13) \\
3\end{array}$ & $(29.6)$ & $\begin{array}{l}\text { Made of pine, yellow, } \\
\text { width of scale mark: } \\
10.0 \mathrm{~mm} \text { scale marks } \\
\text { of jucheondo engraved } \\
\text { without } 24 \text { solar terms }\end{array}$ & $\begin{array}{l}380 \\
(11.5) \\
2\end{array}$ & $\begin{array}{l}\text { engraved jucheon- } \\
\text { do on outer side of } \\
\text { metal goods } \\
\text { ( } 365.25 \text { degrees) } \\
\text { angle of intersec- } \\
\text { tion: } 23.5 \text { degrees }\end{array}$ & $\begin{array}{l}360 \\
(15) \\
3\end{array}$ & $\begin{array}{l}\text { Single ring, red } \\
\text { angle of intersection of } \\
\text { equator: } 23.5 \text { degrees } \\
\text { carved Jucheondo } \\
\text { ( } 365.25 \text { degrees) on the } \\
\text { outer side of the North } \\
\text { and South each side } \\
\text { solar traction device } \\
\text { which is moving the } \\
\text { sun } 1 \text { degree by } 1 \text { day } \\
\text { by pulling a string }\end{array}$ \\
\hline & $\begin{array}{l}\text { Baekdodan- } \\
\text { hwan }\end{array}$ & None & $\begin{array}{l}(23) \\
3.2\end{array}$ & $\begin{array}{l}\text { Made of pine, white, } \\
\text { no scale mark }\end{array}$ & & None & $\begin{array}{l}302 \\
(13.1) \\
9\end{array}$ & $\begin{array}{l}\text { Single ring, white } \\
\text { angle of intersection of } \\
\text { ecliptic: } 5 \text { degrees } \\
\text { North side: } 12 \text { signs } \\
\text { South side: arranged } 27 \\
\text { pins }\end{array}$ \\
\hline \multirow[t]{2}{*}{ Sayuui } & $\begin{array}{l}\text { Sayussangh- } \\
\text { wan }\end{array}$ & $\begin{array}{l}250 \\
(13) \\
3\end{array}$ & 367 & $\begin{array}{l}\text { Tick mark separated at } \\
6.5 \mathrm{~mm} \rightarrow \text { scale marks } \\
\text { engraved }\end{array}$ & $\begin{array}{l}275 \\
(21.2) \\
2\end{array}$ & $\begin{array}{l}\text { showing jucheondo } \\
\text { as } 2.4 \mathrm{~mm} \text { intervals } \\
\text { on outer side }\end{array}$ & $\begin{array}{l}\text { diam- } \\
\text { eter:85 }\end{array}$ & $\begin{array}{l}\text { Installed a globe in- } \\
\text { stead of Sayuui }\end{array}$ \\
\hline & jikgeo & $\begin{array}{l}180 \\
(20) \\
7\end{array}$ & & Lost & & $\begin{array}{l}\text { made of metal, } \\
\text { Gyuhyeong is lost }\end{array}$ & & None \\
\hline \multirow[t]{3}{*}{ Base } & Yongju & $\mathrm{H}: 286$ & $\mathrm{H}: 370$ & $\begin{array}{l}\text { Wooden fish-dragon } \\
\text { carved like table legs }\end{array}$ & $\mathrm{H}: 251$ & $\begin{array}{l}\text { carved detailed } \\
\text { dragon }\end{array}$ & & $\begin{array}{l}\text { Wooden fish-dragon } \\
\text { carved }\end{array}$ \\
\hline & Ounju & $\mathrm{H}: 103$ & & Lost & L:76 & $\begin{array}{l}2 \text { steps round } \\
\text { wooden-pattern } \\
\text { sculpture }\end{array}$ & & $\begin{array}{l}\text { Bronze turtle, pattern of } \\
\text { cloud, beaded decora- } \\
\text { tions }\end{array}$ \\
\hline & Sipjabachim & L:430 & $\mathrm{L}: 568$ & $\begin{array}{l}\text { Making record stated } \\
\text { on bottom of support }\end{array}$ & $\begin{array}{l}\mathrm{L}: 514 \\
(40) \\
30\end{array}$ & & & $\begin{array}{l}\text { Connected as the form } \\
\text { of to body }\end{array}$ \\
\hline
\end{tabular}


and it is a key extant device crafted by a national agency (Lee \& Kim 2007). This armillary sphere is sized similar to that of private armillary spheres, and it is a standard with which to compare extant Joseon armillary spheres.

\subsection{Restoration of Toegye Armillary Sphere}

Historical records that in the 18th century say Goedam Bae Sang-Yeol saw the Toegye armillary sphere at Dosanseowon and crafted an armillary sphere. ${ }^{4}$ Based on these records, the basic design drawings of the Toegye armillary sphere was crafted by referring to the Goedam armillary sphere. The Sipjabachim (cross support) and Yongju of the Goedam armillary sphere are well preserved to identify the structure of an armillary sphere. Thus, these were measured, and the various remaining rings of the Toegye armillary sphere were also measured; thus, an armillary sphere was designed and restored as in Fig. 3.

\subsection{Design of Goedam Armillary Sphere}

Based on the measurement and analysis of the Goedam armillary sphere (Fig. 4-left), a structural drawing and restoration design drawings were completed. Fig. 4-right

${ }^{4}$ This Honsang, which has thus far been known to be that of Toegye, was identified as that of Goedam, according to the recording on the inside. Also, details on Goedam armillary sphere are presented.

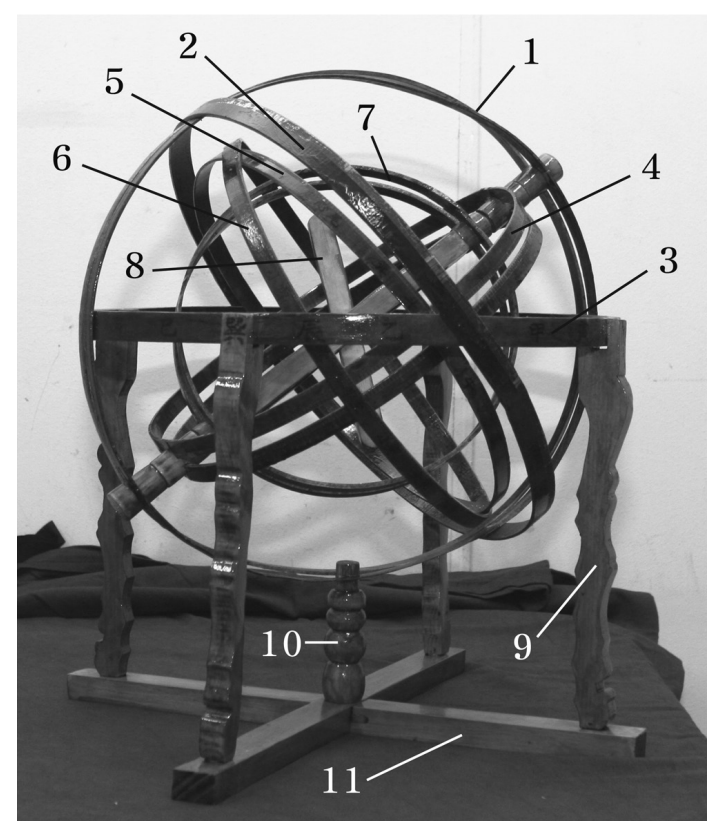

Fig. 3. Restored Toegye armillary sphere. 1. Cheongyeongheukssanghwan, 2. Cheonwijeokdanhwan, 3. Jipyeonghwan, 4. Samsinheukssanghwan, 5. Jeokdodanhwan, 6. Hwangdodanhwan, 7. Sayussanghwan, 8.Gyuhyeong, 9. Yongju, 10. Ounju, 11. Sipjabachim. shows a structural drawing to identify the structure and component names of the Goedam armillary structure, and this drawing denotes the name of each component. Fig. 5 shows part of the restoration design drawing.

\subsection{Restoration of Uam Armillary Sphere}

We restored Uam armillary sphere as an actual working model through a minute analysis regarding original one. The horizontal ring, Yongju and Ounju of restored one are retain its original form and the scale marks and characters are etched on each restored bronze Jeokdodanhwan and Hwangdodanhwan.

The 28 orient traditional constellations $(\mathrm{Su})$ are arranged from East to West on outer side of Jeokdodanhwan which shows the movement celestial bodies from East to West. These 28 orient traditional constellations are arranged as follows: Jinsu $\rightarrow$ Ikusu $\rightarrow$ Jangsu $\rightarrow$ Seongsu $\rightarrow$ Ryusu $\rightarrow$ Gwisu $\rightarrow$ Jeongsu $\rightarrow$ Samsu $\rightarrow$ Jasu $\rightarrow$ Pilsu $\rightarrow$ Myosu $\rightarrow$ Wisu $\rightarrow$ Nusu $\rightarrow$ Gyusu $\rightarrow$ Byeoksu $\rightarrow$ Silsu $\rightarrow$ Wisu $\rightarrow$ Heosu $\rightarrow \mathrm{Yeosu} \rightarrow \mathrm{Usu} \rightarrow \mathrm{Dusu} \rightarrow \mathrm{Gisu} \rightarrow \mathrm{Misu} \rightarrow \mathrm{Simsu} \rightarrow \mathrm{Bangsu}$ $\rightarrow$ Jeosu $\rightarrow$ Hangsu $\rightarrow$ Gaksu. The interval of these 28 constellations is not consistent, but their total angle is 365.25 degrees.

Hwangdodanhwan is sun's annual path on the celestial globe and it decline 24 degrees than Jeokdodanhwan. The 24 divisions of the year (Jeolgi) arranged from East to West on outer side of Hwangdodanhwan like as Jeokdodanhwan. These 24 divisions of the year are arranged as follows: Dongji (winter solstice) $\rightarrow$ Sohan $\rightarrow$ Daehan $\rightarrow I p c$ hun $\rightarrow$ Usoo $\rightarrow$ Gyeongcheop $\rightarrow$ Chunbun (spring equinox) $\rightarrow$ Cheongmyeong $\rightarrow$ Goku $\rightarrow$ Ipha $\rightarrow$ Soman $\rightarrow$ Mangjong $\rightarrow$ Haji (summer solstice) $\rightarrow$ Soseo $\rightarrow$ Daeseo $\rightarrow$ Ipha $\rightarrow$ Cheoseo $\rightarrow$ Baengno $\rightarrow$ Chubun (autumn equinox) $\rightarrow$ Hallo $\rightarrow$ Sanggang $\rightarrow$ Soseol $\rightarrow$ Daeseol.

The Uam armillary sphere's polar axis, namely, Jikgeo, spreads symmetrically from the center to both south and north; the lower end is long and pointed (Fig. 6-left). It is deemed that the pointed part, as the handle, was taken and used to rotate the polar axis(Fig. 6-right). This rotation handle of the South Pole cannot be discovered in any other extant armillary spheres. ${ }^{5}$ All components including this were manufactured and the operating model of the Uam armillary sphere was restored. Fig. 7 shows a

\footnotetext{
${ }^{5}$ The catalogue of exhibits displayed at the special exhibition at Japan's Osaka Museum, 1999, October 6-11, presents extant armillary spheres dating back to the second half of Edo. The armillary sphere has a twolevel gear at the south, and a handle designed to manually rotate the gear. This is structurally similar to the extant armillary sphere kept by Soongsil University Korean Christian Museum, and it is deemed to have developed from the Uam armillary's polar axis rotation system.
} 

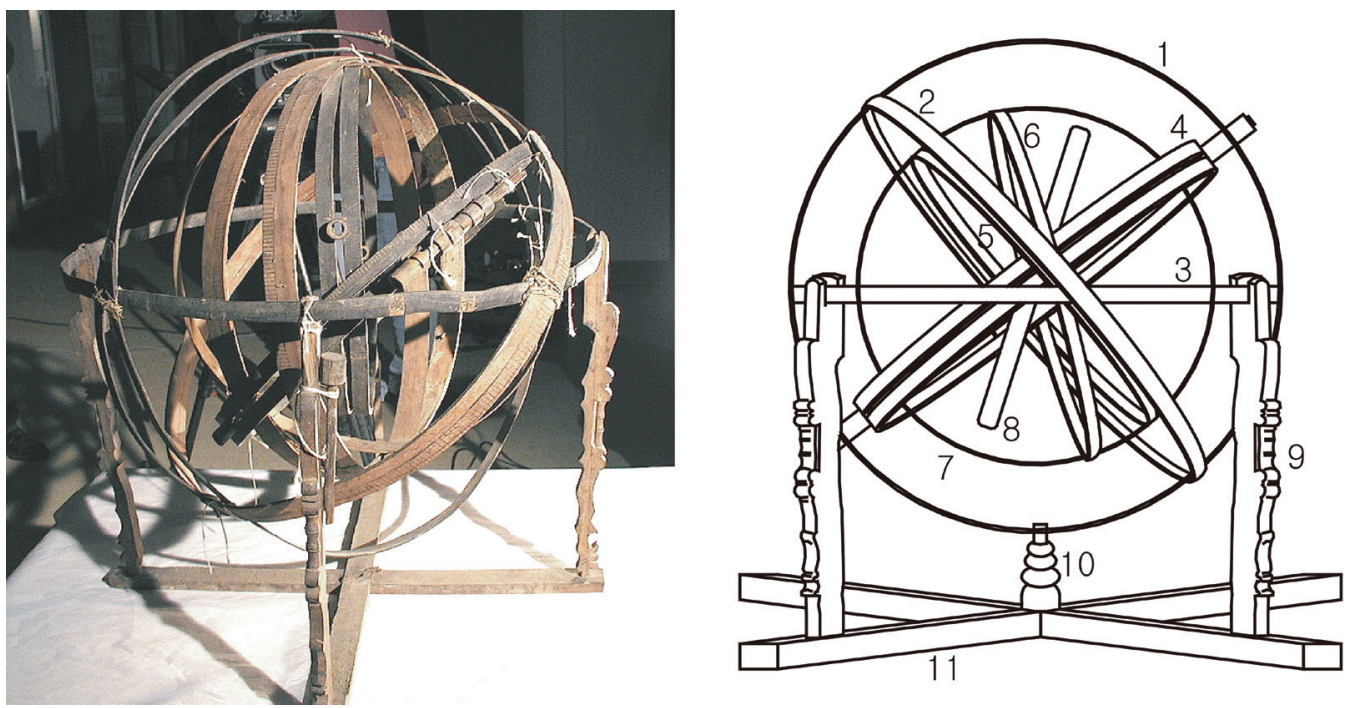

Fig. 4. Goedam armillary sphere (left) and keys map (right). 1. Cheongyeongheukssanghwan, 2. Cheonwijeokdanhwan, 3. Jipyeonghwan, 4. Samsinheukssanghwan, 5. Jeokdodanhwan, 6. Hwangdodanhwan, 7. Sayussanghwan, 8.Gyuhyeong, 9. Yongju, 10. Ounju, 11. Sipjabachim.

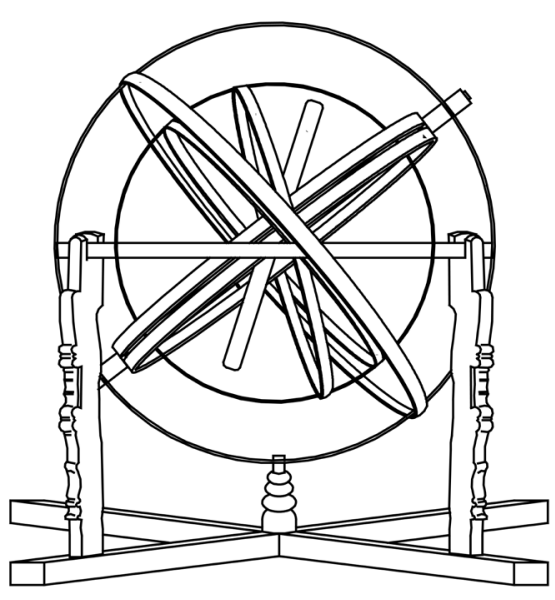

(a)

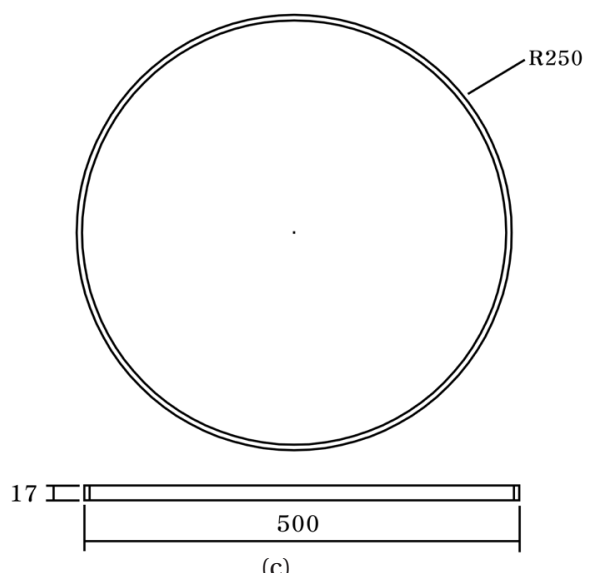

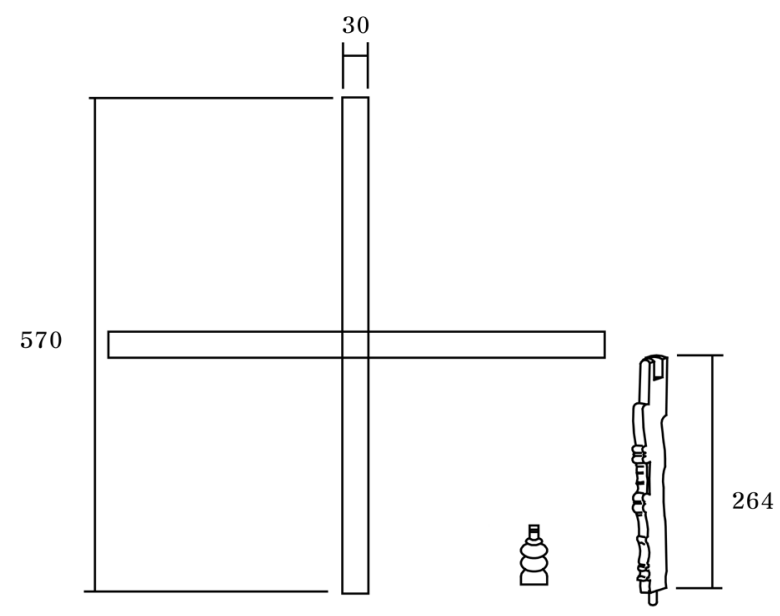

(b)

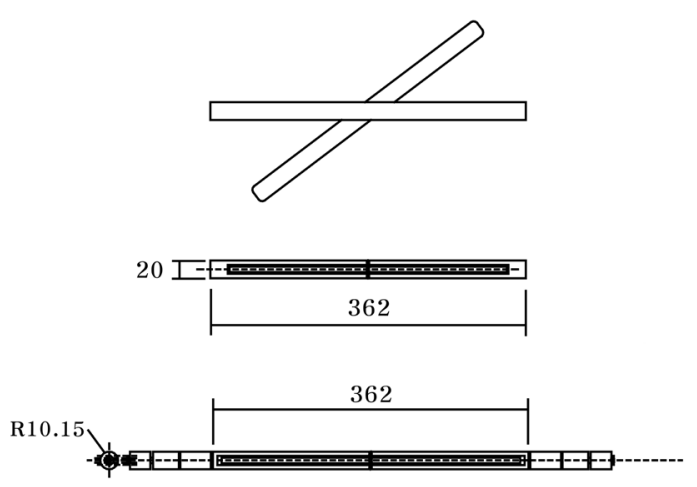

(d)

Fig. 5. Blueprints of Goedam armillary sphere parts for restoration. (a) Model result. (b) Sipjabachim, Yongju, Ounju. (c) Jipyeonghwa. (d) Parts of connection pole-axis, Jikgeo and Gyuhyeong. 


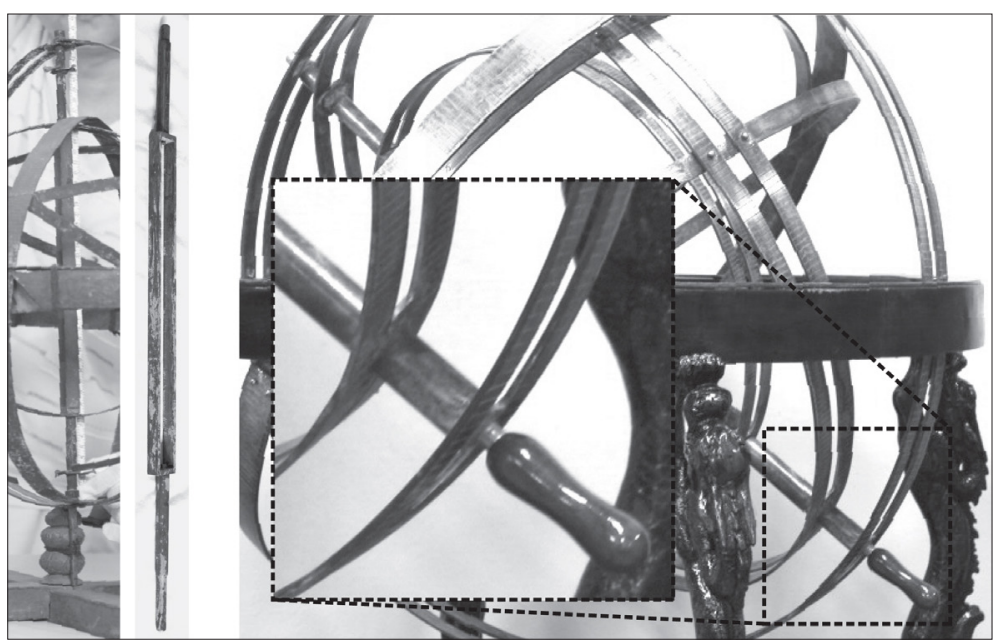

Fig. 6. Pole-axis and Jikgeo of Uam armillary sphere (left), resorted pole-axis rotation handle (right).
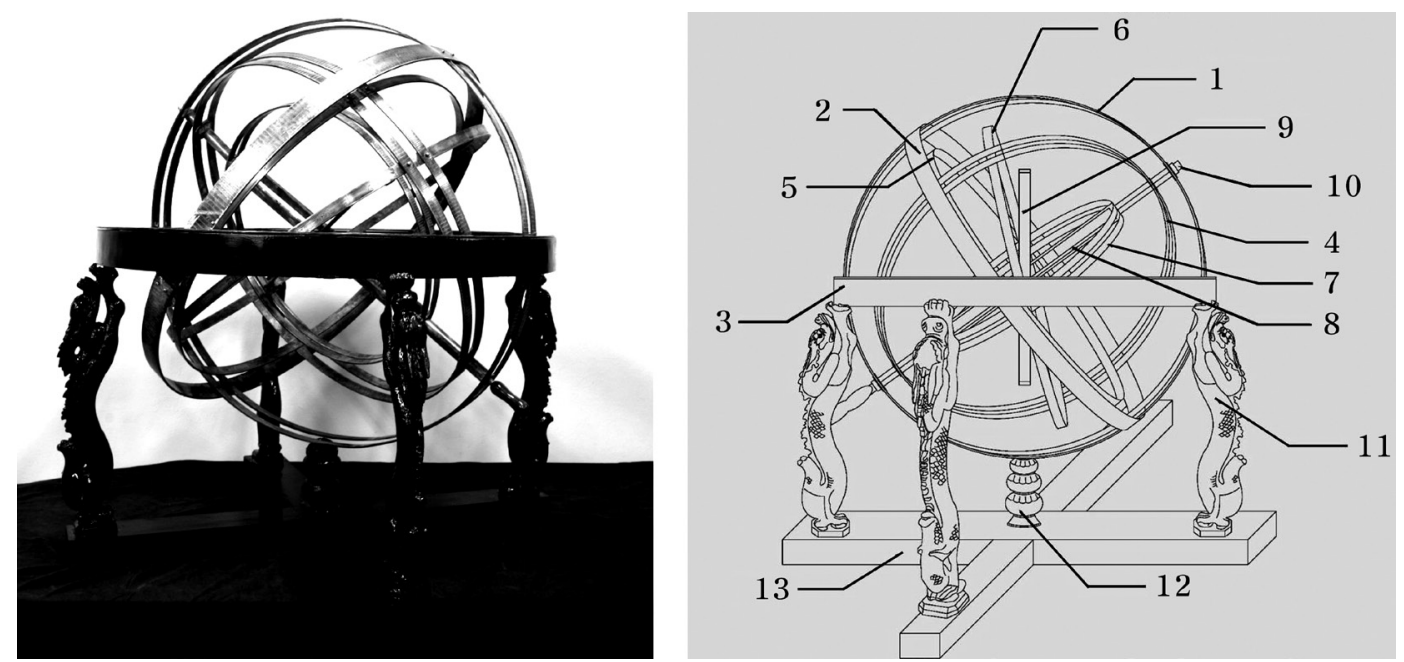

Fig. 7. Restored Uam armillary sphere (left) and keys map (right). 1. Cheongyeongheukssanghwan, 2. Cheonwijeokdanhwan, 3. Jipyeonghwan, 4. Samsinheukssanghwan, 5. Jeokdodanhwan, 6. Hwangdodanhwan, 7. Sayussanghwan, 8.Jikgeo, 9.Gyuhyeong, 10. poleaxis, 11. Yongju, 12. Ounju, 13. Sipjabachim.

structural drawing which features the names of its various components along with the restored shape.

\section{CONCLUSIONS}

Toegye, Goedam and Uam armillary sphere have significant historic value even their bad state of preservation.

Most of Confucian scholars during Joseon era made their own armillary spheres personally and used them as a study-aid tool for studying the principle of nature. The Toegye armillary sphere is a case in point, it was manufactured by his disciple Ganjae Lee Deok-Hong (1541 1596), and the Memoir on Toegye ${ }^{6}$ says, "The master (Toegye) allowed his students to play the game of throwing arrows into a jar in a bid to observe their virtuous personality. He also ordered Deok-Hong to craft Seongiokhyeong and observe astronomical phenomena (Lee 2006)." Lee DeokHong was the most competent Confucian scholar among Toegye's disciples; however, unfortunately, only a few components of the precious armillary atmospheres used by him have survived to present day, making it impossible to accurately identify their structures and shapes. Fortunately, in this study, the Toegye armillary sphere was able to be restored by investigating and estimating the

${ }^{6}$ Kim Seong-il (1538 1593), A Serial of Hakbong's Collection of Literary Works, vol. 5. 
structure of Goedam armillary sphere which was crafted on the basis of the Toegye armillary sphere.

The National Treasure No. 230, armillary sphere of Song I-yeong Honcheonsigye which was installed at Hongmungwan (Office of Special Advisors) after it was manufactured by Gwansanggam (Bureau of Astronomy), is Joseon's key armillary sphere. Table 2 shows a comparative analysis of the characteristics of extant Toegye, Goedam, Uam, and Song I-Yeong armillary spheres.

Of the four armillary spheres, the Goedam armillary sphere is the largest, and it used unique-color wood components unlike other armillary spheres. Its various rings' Jucheondo (circumference of celestial globe) scale marks are expressed every 10 degrees so as to allow a fast and convenient measurement of angles. Its various rings' colors and materials were used according to functions and names. Also it contains Baekdodanhwan unlike other private armillary spheres. Although some of its components have lost and been damaged, it is equipped with all components that could be seen in the traditional Seongiokhyeongdo (armillary sphere chart) depicted in Seojeon.

In particular, characteristically, 28 constellations are depicted on the equatorial ring. The 28 constellation's names and charts are useful in performing astronomical observation or offering education on astronomy, and this feature cannot be discovered in other extant East Asian armillary spheres. Also, our scientific investigations revealed that the manufacturing year, the manufacturer and the manufacturing backgrounds were inscribed on the floor of the wood Sipjabachim of the armillary sphere.

The extant Uam armillary sphere is partially damaged; some of its components are misplaced and some other components are lost. However, its structure consists of wood frames and metal rings, making it particular. The metal rings, which strongly cover the wood Jipyeonghwan, feature 24 directions and scale marks. Various metal rings are not only well formed, but also feature accurate scale mark carvings.

In the process of restoring the Uam armillary sphere, the rotation handle of the polar axis was manufactured. Various rings were deigned to be driven not by hand but by operating the rotation axis. This structure cannot be discovered in other extant armillary spheres. In particular, the Uam armillary sphere is the only extant relic that was manufactured by Lee Min-Cheol, the then best craftsman of armillary spheres; it is all the more valuable.

When we restore Korean traditional scientific and technological heritages with highly acclaimed creativity which are long forgotten, we can newly understand the scientific spirit of our forefathers. Also, by restoring armillary spheres used by Confucian scholars, we had an opportunity to understand the thoughts on nature and science and cosmological view of our well-reputed scholars who sought to explore the skies and natural phenomena.

\section{ACKNOWLEDGEMENTS}

This work was supported by the research grant of the Chungbuk National University in 2008.

\section{REFERENCES}

Jeong, J. H., Lee, Y. S., \& Lee, Y. B. 2007, Astronomy and Seongiokhyeong of Goedam Bae Sang-Yeol (Bonghwa: Cheongryangsan Museum), pp.80-81

Kim, S. H. 2007, PhD Thesis, Chung-Ang University

Lee, J. G. 2006, Haven of Toegye, Honcheonui, Andong MBC Company Celebrates 36th Anniversary Special Documentary (Andong: Andong MBC Company)

Lee, S. J. 2007, Comprehensive Consideration regarding Hwayanggugok and Its Cultural Heritage, International Conference for Commemoration of Uam's 400th Birthday (Cheongju: Uam Research Institute of Chungbuk National University), p.138

Lee, Y. S. \& Kim, S. H. 2007, JASS, 24, 167

Lee, Y. S., Kim, S. H., \& Nam, M. H. 2001, JKAS, 34, 47

\section{INDEX}

12 Si 12時, twelve double-hours; Myo 卯: hare (a.m. 5 7), Yu 西: cock (p.m. 5 7), etc.

24 Jeolgi 節氣, 24 divisions of the year; These 24 divisions of the year are arranged as follows: Dongji 冬至, Sohan 小 寒, Daehan 大寒, Ipchun 立春, Usoo 雨水, Gyeongcheop 驚熱, Chunbun 春分, Cheongmyeong 淸明, Goku 穀雨, Ipha 立夏, Soman 小滿, Mangjong 芒種, Haji 夏至, Soseo 小署, Daeseo 大暑, Ipha 立秋, Cheoseo 處暑, Baengno 白 露, Chubun 秋分, Hallo 寒露, Sanggang 霜降, Soseol 小雪, Daeseol 大雪

$28 \mathrm{Su}$ 宿, 28 constellations; Gaksu 角宿, Hangsu六宿, Jeosu 氏 宿, Bangsu 房宿, Simsu 心宿, Misu 尾宿, Gisu 箕宿, Dusu 斗宿, $U s u$ 牛宿, Yeosu, 女宿, Heosu 虛宿, Wisu危宿, Silsu 室宿, Byeoksu 壁宿, Gyusu 奎宿, Nusu 婁宿, Wisu 胃宿, Myosu 昂宿, Pilsu 畢宿, Jasu 觜宿, Samsu 參宿, Jeongsu 井宿, Gwisu 鬼宿, Ryusu 柳宿, Seongsu 星宿, Jangsu 張宿, 


\section{Ikusu 翼宿, Jinsu 軫宿}

Baekdodanhwan 白道單環, moon-path single ring Cheongyeongheukssanghwan 天經黑雙環, meridian double ring Cheonwijeokdanhwan 天緯赤單環, fixed equator single ring Dosanseowon 陶山書院, Dosan Confucian Academy Ganjae Lee Deok-Hong 艮齋李德弘(1514 1596)

Geogeukdo 去極度, similar to declination value of the equatorial coordinates system

Goedam Bae Sang-Yeol 槐潭 拜相說(1759 1789)

Gwansanggam 觀象監, Bureau of Astronomy

Gyuhyeong 窺衡, sighting alidade

Heoncheonseol 渾天說, Enveloping Heaven Theory

Honcheonseol 渾天說

Honcheonsigye 渾天時計, armillary clock

Honcheonui 渾天儀, armillary sphere

Hongmungwan 弘文館, Office of Special Advisors

Honsang 渾象, celestial globe

Hwan 環, ring

Hwangdodanhwan 黄道單環, ecliptic single ring

Hyeonjong 顯宗, King Hyeonjong of Joseon (1641-1674)

Ipsudo 入宿度, similar to right ascension value of the equatorial coordinates system

Jeokdodanhwan 赤道單環, revolving equator single ring
Jikgeo 直距

Jipyeonghwan 地平環, fixed outer terrestrial-horizon single ring Jucheondo 周天度, 365.2575度

Jucheondo 周天度, circumference of celestial globe, 365.2575度

Lee Min-Cheol 李敏哲(1631 1715)

Okjingak玉振閣, Okjingak pavilion

Ounju鰲雲柱, turtle pillar

Samgyeong 三經, Three Classics (詩經, 書經, 周易)

Samsinheukssanghwan 三辰黑雙環, solstitial-colure double ring Samsinui 三辰儀, revolving sidereal component

Saseo 四書, Four Books (論語, 孟子, 中庸, 大學)

Sayussanghwan 四遊雙環, mobile declination double ring Sayuui 四遊儀

Seojeon 書傳

Seongiokhyeong 玫璣玉衡, armillary sphere

Seongiokhyeongdo 璇璣玉衡圖, armillary sphere chart

Shun 舜, Chinese leader

Sipjabachim 十字받침, cross prop

Song I-Yeong 宋以頴(1619 1674)

Toegye Lee Hwang 退溪 李滉(1501 1570)

Uam Song Si-Yeol 尤庵 宋時烈(1607 1689)

Yongju 龍柱, dragon pillar

Yukhapui 六合義, fixed outer terrestrial-coordinate component 